Manuela Ingaldi ${ }^{1}$, Dorota Klimecka-Tatar ${ }^{2}$

\title{
ENVIRONMENTAL MANAGEMENT SYSTEMS
}

\begin{abstract}
Management systems, especially environmental management systems, are very helpful tools in environmental management in companies. A management system is the framework of processes and procedures used to ensure that an organization can fulfil all tasks required to achieve its objectives. The basic information about environmental management system according to ISO 14000 and EMAS was presented. Fundamental differences of these two systems were also shown.
\end{abstract}

Key words: EMS, ISO 14000, EMAS

\section{Introduction}

Management systems, especially environmental management systems, are very helpful tools in environmental management in companies. A management system is the framework of processes and procedures used to ensure that an organization can fulfil all tasks required to achieve its objectives (LESTYÁNSZKA ŠKU゚RKOVÁ K., INGALDI M. 2014).

Environmental management system (EMS) refers to the management of an organization's environmental programs in a comprehensive, systematic, planned and documented manner. It includes the organizational structure, planning and resources for developing, implementing and maintaining policy for environmental protection (PUSTĚJOVSKÁ P., JuRSOVÁ S., BROŽOVÁ S. 2013).

EMS can be define as "a system and database which integrates procedures and processes for training of personnel, monitoring, summarizing, and reporting of specialized environmental performance

${ }^{1}$ Dr inż., Politechnika Częstochowska, Wydział Zarządzania, Instytut Inżynierii Produkcji, e-mail: manuela@gazeta.pl

${ }^{2}$ Dr inż., Politechnika Częstochowska, Wydział Zarządzania, Instytut Inżynierii Produkcji, e-mail: klimt@wip.pcz.pl 
information to internal and external stakeholders of a firm" (BOIRAL O. 2007).

There are two the most common system: environmental management system according to ISO 14000 and EMAS.

The aim of the article is to present two the most important environmental management systems and their comparison.

\section{The Eco-Management and Audit Scheme (EMAS)}

Excellence in environmental performance is becoming a strong business advantage. Organisations with a proactive approach to environmental challenges look for ways to continually improve their environmental performance and to communicate their environmental achievements to stakeholders and society in general. The EcoManagement and Audit Scheme (EMAS) is the EU's voluntary environmental management instrument that helps organisations in it. EMAS Environmental Management Systems can be used worldwide by companies and organisations of all sizes and types. EMAS registered organisations commit themselves to evaluate, manage and improve their environmental performance ( $3 \times 3$ good reason for EMAS).

EMAS' distinctive key elements are (http://ec.europa.eu/environment/emas/about/summary_en.htm):

- Performance: EMAS is a voluntary environmental management instrument based on a harmonised scheme throughout the EU. Its objective is to improve the environmental performance of organisations by having them commit to both evaluating and reducing their environmental impact, and continuously improving their environmental performance.

- Credibility: The external and independent nature of the EMAS registration process ensures the credibility and reliability of the scheme. This includes both the actions taken by an organisation to continuously improve its environmental performance, and the 
organisation's disclosure of information to the public through the environmental statement.

- Transparency: Providing publicly available information on an organisation's environmental performance is an important aspect of the scheme's objective. It is achieved externally through the environmental statement and within the organisation through the active involvement of employees in the implementation of the scheme. The EMAS logo, which can be displayed on letterheads, adverts for products, activities, and services, is an attractive visual tool which demonstrates an organisation's commitment to improving its environmental performance and indicates the reliability of the information provided.

The Unique Quality of EMAS is primarily the result of the following (EMAS. Verified Environmental Management):

- the environmental review to determine the organisation's current status,

- consistent orientation towards continuous improvement of environmental performance,

- standardised indicators of significant environmental aspects,

- intensive participation of employees,

- an evaluation system that is both transparent and monitored by the Federal Ministry for the Environment through environmental verifiers who are specifically accredited or licensed for EMAS,

- detailed information made available to the public through the validated environmental statement,

- validated legal compliance as a precondition of participation,

- publically accessible register of EMAS Participants.

(Commission Decision establishing the user's guide setting out the steps needed to participate in EMAS) presents general schedule how to implement EMAS (Figure 1). 


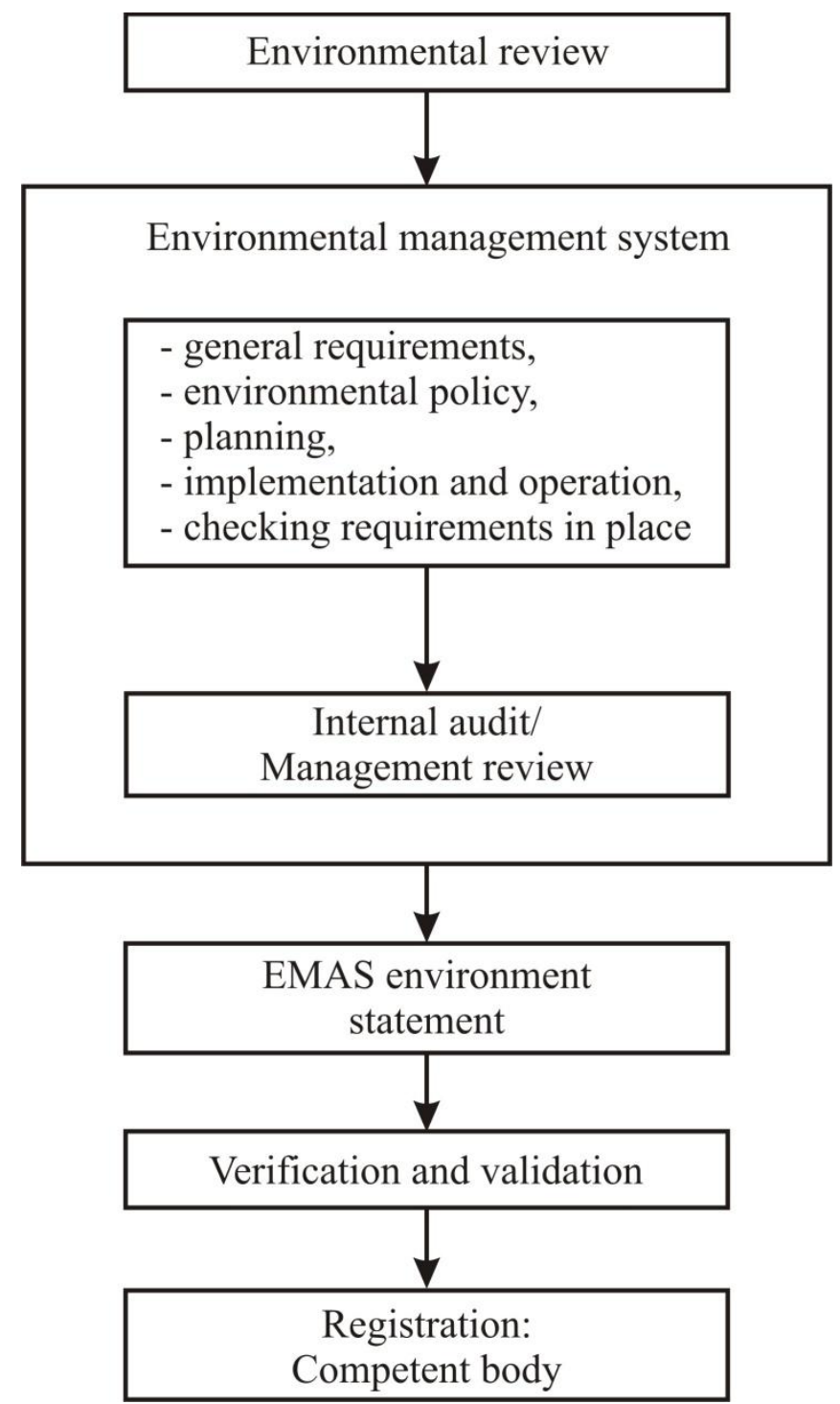

Fig. 1. General schedule for EMAS implementation.

Source: Commission Decision establishing the user's guide setting out the steps needed to participate in EMAS 
There are many benefits from EMAS. European Commission dived all benefits into 4 main group (http://ec.europa.eu/environment/emas/about/summary_en.htm):

1. Enhanced environmental and financial performance:

- high quality environmental management,

- resource efficiency and lower costs,

2. Enhanced risk and opportunity management:

- guarantee of full regulatory compliance with environmental legislation,

- reduced risk of fines related to environmental legislation,

- regulatory relief,

- access to deregulation incentives,

- access to public contracts,

3. Enhanced credibility, transparency and reputation:

- continuous improvement of environmental performance is verified,

- independently validated environmental information,

- use of the EMAS logo as a marketing tool,

- increased business opportunities in markets where green production processes are important,

- better relations with customers, the local and wider community, and regulators,

4. Enhanced employee empowerment and motivation:

- improved workplace environment,

- enhanced employee commitment,

- greater team-building capacity.

\section{Environmental Management System according to ISO 14000}

Environmental management system according to ISO 14000 is one of the most popular management systems. It does not state requirements for environmental performance, but maps out a framework that a company or organization can follow to set up an effective EMS. It can be used by any 
organization that wants to improve resource efficiency, reduce waste, and drive down costs. Using ISO 14001 can provide assurance to company management and employees as well as external stakeholders that environmental impact is being measured and improved (ISO 14001).

Environmental management systems are introduced by standard ISO 14001, that:

- provides a framework for system and provides guidance for the implementation according to the current legal regime and calls for the development of environmental policy in companies,

- the standard itself does not impose direct criteria for the protection of the environment (emission),

- allows self-declaration adequacy, although for most companies it plans to implement control of a third party,

- is the only standard ISO 14000 family, which makes it possible to obtain a certificate of compliance, the rest are support voluntary guidelines,

- plans to develop and implement environmental management system and its integration with all activities of the company.

The most important parts of this standard are:

- determination of significant environmental impacts,

- design and discusses the company's environmental policy,

- preparation of plans and procedures to improve the environment,

- review of the environmental management system of the company's management,

- completion environmental management system.

The purpose of ISO standards of the implementation of environmental reviews has grown into flourishing voluntary implementation of these checks in the 80s and 90s.

The sequence of steps to follow at all stages of implementation of indicators in ISO 14031 are presented in Table 1 and Figure 2. 
Tablex.1. The model of PDCA of ISO 14031 implementation

\begin{tabular}{|c|c|}
\hline PLAN & DO \\
\hline $\begin{array}{l}\text { Selection of indicators based on: } \\
\text { - } \quad \text { significant environmental aspects } \\
\text { in present conditions, } \\
\text { - internal environmental } \\
\text { performance criteria, } \\
\text { - } \quad \text { opinions of interested parties, } \\
\text { based on business plan, } \\
\text { production plan and strategy. } \\
\text { Indicators: ECI, EPI, MPI and OPI }\end{array}$ & 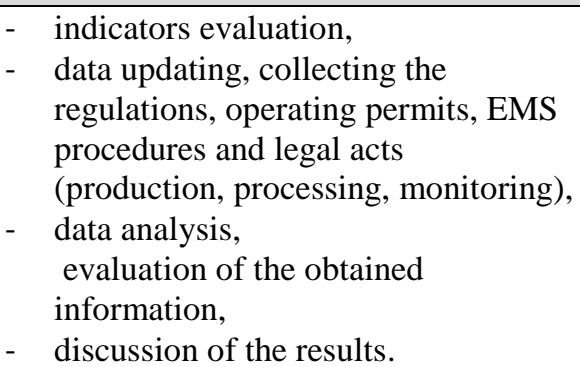 \\
\hline \multicolumn{2}{|c|}{ CHECK \& ACT } \\
\hline \multicolumn{2}{|c|}{$\begin{array}{l}\text { Review and performance improvement. Identification of opportunities of } \\
\text { environmental performance improvement, based on: } \\
\text { - cost and benefit program, } \\
\text { - analysis of progress in environmental performance targets meeting, } \\
\text { - assessment of correctness of the environmental performance criteria and } \\
\text { indicators, } \\
\text { - quality data and methods collection. }\end{array}$} \\
\hline
\end{tabular}

Source: POCHYLUK R., SZYMAŃSKI J. 1999

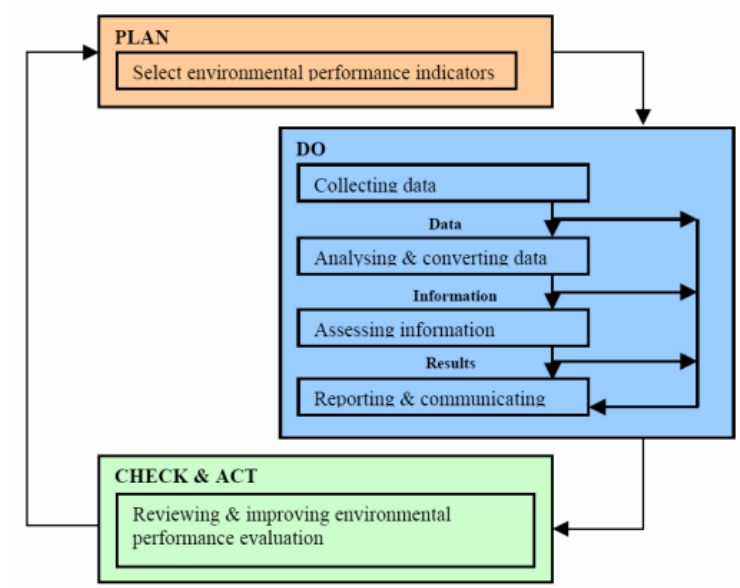

Fig. 3. The model of Plan-Do-Check-Act of ISO 14031 implementation. Source: POCHYLUK R., SZYMAŃSKI J. 1999 
The environmental management system according to ISO 14000 allow company to:

- improve levels of compliance to environmental legislation,

- reduce waste and an increase in efficiency,

- reduce environmental liability and risk,

- increase stakeholder confidence,

- identify cost savings with greater emphasis on resource, waste and energy management,

- develop the corporate image and credibility,

- quantify, monitor and control the impact of operations on the environment, now and in the future,

- ensure legislative awareness and compliance,

- improve environmental performance of supply chain,

- protect the company, assets, shareholders and directors,

- potentially decrease public liability insurance costs for your organisation,

- grow your access to business partners and potential customers.

\section{Comparison of ISO 14001 and EMAS}

All organisations which are included in the EMAS-Register run an environmental management system according to the EMAS requirements. ISO 14001is an integral part of EMAS, so in the same time these organisations automatically comply with the requirements that the international standard demands as well.

The main differences between both systems are listed in Table 2 .

Table.2. EMAS and ISO/EN ISO 14001

\begin{tabular}{|l|l|l|}
\hline Element & \multicolumn{1}{|c|}{ EMAS } & \multicolumn{1}{c|}{ ISO/EN ISO 14001 } \\
\hline Status & $\begin{array}{l}\text { Under legal bases (EU Member } \\
\text { States and EEA countries). } \\
\text { Regulation of the European }\end{array}$ & $\begin{array}{l}\text { Under no legal bases. } \\
\text { (International: world } \\
\text { wide) ISO standard under }\end{array}$ \\
\hline
\end{tabular}




\begin{tabular}{|c|c|c|}
\hline & $\begin{array}{l}\text { Parliament and the Council } \\
\text { under public law }\end{array}$ & private law \\
\hline Organisation & $\begin{array}{l}\text { The entity to be registered shall } \\
\text { not exceed the boundaries of } \\
\text { the Member State, and it is } \\
\text { intended to go towards entities } \\
\text { and sites }\end{array}$ & $\begin{array}{l}\text { Does not go towards } \\
\text { entities or sites }\end{array}$ \\
\hline $\begin{array}{l}\text { Environmental } \\
\text { policy }\end{array}$ & $\begin{array}{l}\text { Included commitment to } \\
\text { continual improvement of } \\
\text { environmental performance of } \\
\text { the organisation }\end{array}$ & $\begin{array}{l}\text { Does not include a } \\
\text { commitment to the } \\
\text { continual improvement of } \\
\text { environmental } \\
\text { performance but of the } \\
\text { performance of the system }\end{array}$ \\
\hline $\begin{array}{l}\text { Initial } \\
\text { environmental } \\
\text { review }\end{array}$ & $\begin{array}{l}\text { Obligatory preliminary review, } \\
\text { when is the first time that the } \\
\text { organisation sets its } \\
\text { environmental status }\end{array}$ & $\begin{array}{l}\text { Initial review is } \\
\text { recommended, but not } \\
\text { required }\end{array}$ \\
\hline $\begin{array}{l}\text { Environmental } \\
\text { aspects }\end{array}$ & $\begin{array}{l}\text { Identification and evaluation of } \\
\text { the environmental aspects } \\
\text { (direct and indirect). } \\
\text { Establishment of criteria for } \\
\text { assessing the significance of } \\
\text { the environmental aspects }\end{array}$ & $\begin{array}{l}\text { Required only a procedure } \\
\text { able to identify } \\
\text { environmental aspects }\end{array}$ \\
\hline $\begin{array}{l}\text { Legal } \\
\text { compliance }\end{array}$ & $\begin{array}{l}\text { Obligatory to demonstrate it. } \\
\text { Required full legal compliance. } \\
\text { There is a compliance-audit }\end{array}$ & $\begin{array}{l}\text { Only commitment to } \\
\text { comply with applicable } \\
\text { legal requirements. There } \\
\text { is no compliance-audit }\end{array}$ \\
\hline $\begin{array}{l}\text { External } \\
\text { communication }\end{array}$ & $\begin{array}{l}\text { Open dialogue with the public. } \\
\text { Public Environmental } \\
\text { Statement (validated for } \\
\text { verifiers) }\end{array}$ & $\begin{array}{l}\text { Not open dialogue with } \\
\text { the public. Only is } \\
\text { required to respond to } \\
\text { relevant communication } \\
\text { from external interested } \\
\text { parts. Control by public is } \\
\text { not possible }\end{array}$ \\
\hline $\begin{array}{l}\text { Continual } \\
\text { improvement }\end{array}$ & Required annual improvement & $\begin{array}{l}\text { Required periodically } \\
\text { improvement without a } \\
\text { defined frequency }\end{array}$ \\
\hline $\begin{array}{l}\text { Management } \\
\text { review }\end{array}$ & $\begin{array}{l}\text { Is wider and requires an } \\
\text { evaluation of the environmental } \\
\text { performance of the }\end{array}$ & $\begin{array}{l}\text { Required an } \\
\text { environmental } \\
\text { performance in the }\end{array}$ \\
\hline
\end{tabular}




\begin{tabular}{|c|c|c|}
\hline & $\begin{array}{l}\text { organization, based in a } \\
\text { performance-audit }\end{array}$ & $\begin{array}{l}\text { management, but not } \\
\text { through a performance } \\
\text { audit }\end{array}$ \\
\hline $\begin{array}{l}\text { Contractors and } \\
\text { suppliers }\end{array}$ & $\begin{array}{l}\text { Required influence over } \\
\text { contractors and suppliers }\end{array}$ & $\begin{array}{l}\text { Relevant procedures are } \\
\text { communicated to } \\
\text { contractors and suppliers }\end{array}$ \\
\hline $\begin{array}{l}\text { Employees } \\
\text { involvement }\end{array}$ & $\begin{array}{l}\text { Active involvement of } \\
\text { employees and their } \\
\text { representatives }\end{array}$ & No \\
\hline $\begin{array}{l}\text { Internal } \\
\text { environmental } \\
\text { auditing }\end{array}$ & $\begin{array}{l}\text { Includes: system-audit, a } \\
\text { performance-audit (= } \\
\text { evaluation of environmental } \\
\text { performance) and an } \\
\text { environmental compliance- } \\
\text { audit (=determination of legal } \\
\text { compliance) }\end{array}$ & $\begin{array}{l}\text { Included only system } \\
\text { audit against the } \\
\text { requirements of the } \\
\text { standard }\end{array}$ \\
\hline Auditor & $\begin{array}{l}\text { Required the independence of } \\
\text { the auditor }\end{array}$ & $\begin{array}{l}\text { Advised the independence } \\
\text { of the auditor }\end{array}$ \\
\hline Audits & $\begin{array}{l}\text { Check for improvement of } \\
\text { environmental performance. } \\
\text { Frequency required: } 3 \text { year } \\
\text { cycle during which all areas are } \\
\text { verified at least once }\end{array}$ & $\begin{array}{l}\text { Check environmental } \\
\text { system performance. No } \\
\text { frequency required }\end{array}$ \\
\hline $\begin{array}{l}\text { External } \\
\text { verification }\end{array}$ & $\begin{array}{l}\text { Accredited environmental } \\
\text { verifiers }\end{array}$ & No \\
\hline $\begin{array}{l}\text { Verification/ } \\
\text { Certification } \\
\text { Scope }\end{array}$ & $\begin{array}{l}\text { Verifiers accredited according } \\
\text { to NACE codes }\end{array}$ & $\begin{array}{l}\text { Certifiers accredited } \\
\text { according to EAC code }\end{array}$ \\
\hline $\begin{array}{l}\text { Authorities are } \\
\text { informed }\end{array}$ & $\begin{array}{l}\text { Obligation by Validation of } \\
\text { Environmental Statement }\end{array}$ & No obligation \\
\hline Logo & Yes & No \\
\hline
\end{tabular}

Source: EMAS - Factsheet. EMAS benefits. May 2008

\section{Summary}

In a free market economy different management systems are the basis of the management in the companies. They can relate to the management of quality, environment, etc. Their implementation is not only part of 
marketing, but often the basis for signing the contracts (KARDAS E., BROŽOVÁ S. 2013).

The environmental management system is a set of processes and practices that enable an organization to reduce its environmental impacts and increase its operating efficiency. The environmental management system enables organizations to improve their environmental performance through a process of continuous improvement. It is therefore important to convince managers of companies to be interested in such systems.

Popularity of the implementation of the environmental management systems continues to grow - both in Poland and in the world. It should be noted, however, that this popularity in Poland concerns system according to ISO 14000. When it comes to EMAS, in Poland there are few companies that have decided on its implementation.

\section{Bibliography}

1. $3 \times 3$ good reason for EMAS. Improve your environmental performance with the premium standard in environmental management. http://ec.europa.eu/environment/emas (11.05.14).

2. A guide to corporate environmental indicators. Federal Environment Ministry, Bonn, Federal Environmental Agency, Berlin 1997.

3. BOIRAL O. 2007. Corporate Greening Through ISO 14001: A Rational Myth?. Organisation Science, vol. 18, no. 1, pp. 127-146.

4. Commission Decision of 4 March 2013 establishing the user's guide setting out the steps needed to participate in EMAS, under Regulation (EC) No 1221/2009 of the European Parliament and of the Council on the voluntary participation by organisations in a Community eco-management and audit scheme (EMAS).

5. EMAS - Factsheet. EMAS benefits. February 2011. http://ec.europa.eu/environment/emas (09.07.14). 
6. EMAS. Verified Environmental Management. Systematic Environment Management. Creating Added Value With EMAS. The Differences between EMAS and ISO 14001. Umwelt Gutachter Ausschuss.

7. http://ec.europa.eu/environment/emas/about/summary_en.htm (02.06.14).

8. ISO 14001 - Environmental Management.

9. JASCH CH. 2000. Environmental performance evaluation and indicators. Journal of Cleaner Production, No 8, pp. 79 - 88.

10. Kardas E., BroŽovÁ S. 2013. Situation in Waste Treatment in Poland. [In:] METAL 2013. 22nd International Conference on Metallurgy and Materials. Conference Proceedings. May 15th - 17th 2013, Brno, Hotel Voroněž I, Brno, Czech Republic, Tanger, Ltd., pp. 1773 - 1778.

11. LESTYÁNSZKA ŠKƯRKOVÁ K., INGALDI M. 2014. Recycling process of the aluminium cans as an example of the renewable material sources. Advanced Materials Research Vol. 1001, pp. 103-108.

12. Pochyluk R., SZYMAŃSKI J. 1999. Ocena efektywności działań środowiskowych $i$ benchmarking - zastosowanie normy ISO 14031. Problemy Ocen Środowiskowych No 3.

13. PustěJovskÁ P., JuRsovÁ S., BrožOVÁ S. 2013. Technical-economic prospects of utilization of alternative ironmaking techniques in metallurgy. [In:] METAL 2012: 21th International Conference on Metallurgy and Materials: May 23th - 25th 2012, Hotel Voroněž I, Brno, Czech Republic, Tanger, Ltd., pp. 1729 - 1734.

14. Putnam D. 2002. ISO 14031: Environmental Performance Evaluation. Draft Submitted to Confederation of Indian Industry for publication in their Journal. 